
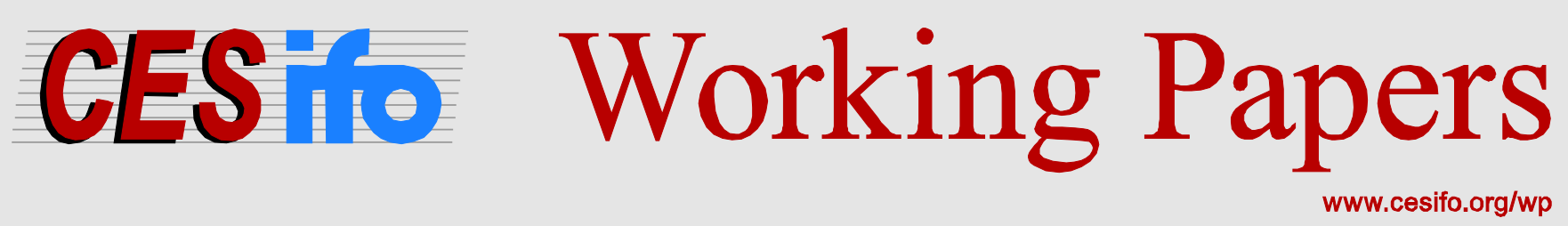

\title{
Human Capital and National Institutional Quality: Are TIMSS, PISA, and National Average IQ Robust Predictors?
}

\author{
Garett Jones \\ Niklas Potrafke \\ CESIFO WORKING PAPER NO. 4790 \\ CATEgory 2: PUBliC CHOICE \\ MAY 2014 \\ An electronic version of the paper may be downloaded \\ - from the SSRN website: Www.SSRN.com \\ - from the RePEc website: Www.RePEc.org \\ - from the CESifo website: www.CESifo-group.org/wp
}

\section{CESifo}




\title{
Human Capital and National Institutional Quality: Are TIMSS, PISA, and National Average IQ Robust Predictors?
}

\begin{abstract}
Is human capital a robust predictor of good institutions? Using a new institutional quality measure, the International Property Rights Index (IPRI), we find that cognitive skill measures are significant, robust, and large in magnitude. We use two databases of cognitive skills: estimates of national average IQ from Lynn and Vanhanen (2012a) and estimates of cognitive ability based on Programme for International Student Assessment (PISA) and Trends in International Mathematics and Science Study (TIMSS) scores estimated by Rindermann et al. (2009). The Rindermann cognitive ability scores estimate mean performance as well as performance at the 5th and 95th percentiles of the national population. National average IQ and the 95th percentile of cognitive ability are both robust predictors of overall institutional quality controlling for legal system, GDP per capita, geography dummies, and years of total schooling. Some possible microfoundations of this relationship are discussed.
\end{abstract}

JEL-Code: D730, I200.

Keywords: institutions, human capital, intelligence, PISA.

Garett Jones

Department of Economics George Mason University

USA - Fairfax, VA 22030

jonesgarett@gmail.com
Niklas Potrafke

Ifo Institute - Leibniz Institute for

Economic Research

at the University of Munich

Poschingerstrasse 5

Germany - 81679 Munich

potrafke@ifo.de

This paper has been accepted for publication in Intelligence. 


\section{Introduction}

Does human capital improve economic institutions? We provide new evidence on this important question, and in cross-country regressions find that standardized test scores, including estimates of national average IQ are robust predictors of institutional quality as measured by the International Property Rights Index (IPRI).

The psychometric and organizational behavior literatures provide evidence that human capital predicts overall employee competence, a trait that is likely important in creating well-run government institutions. For instance, in reviewing a large literature on IQ and job performance, Côté and Miners (2006) note that "[c]ognitive intelligence is positively related to the dimensions of job performance-task performance and organizational citizenship behavior (OCB) - in most, if not all jobs" (p. 5). An earlier literature review went further, saying that "if an employer were to use only intelligence tests and select the highest scoring applicant for each job...overall performance from the employees selected would be maximized" (Ree \& Earles, 1992, p. 88). Taken as a whole, the psychometric and organizational psychology literatures support the hypothesis and workers with high average cognitive skill are more likely to be competent at their jobs, including at government jobs.

Economic theory provides reasons for why a relationship between human capital and economic institutions may hold. One line of supportive theory comes from the reliable relationship between standardized test scores and patience: Psychologists and economists alike have found that those who perform better on IQ and related cognitive tests are more likely to behave patiently (Dohmen et al., 2010; Shoda et al., 1990; Warner \& Pleeter, 2001). The finding is sufficiently routine that Shamosh and Gray (2008) have a meta-analysis of psychology studies on the topic. According to economic theory, patience should improve economic institutions through at least three channels: 
1. Barro and Gordon (1983) show that the time inconsistency problem can be partly solved if the government is patient. The government's promise to respect property rights ex post is time inconsistent in a one-shot game but better equilibria are possible if governments are sufficiently patient, and the greater the level of patience, the better the possible outcome. For instance, a short-sighted government may decide to confiscate and redistribute wealth immediately rather than give businesspeople an incentive to accumulate productive capacity that could eventually be modestly taxed and redistributed over a longer horizon. The patient government is less likely to kill the goose that lays the golden eggs.

2. If politics is a repeated game of individuals or factions that choose to "wait or predate" then a public good or prisoner's dilemma arises. Therefore, game theory's folk theorem applies. The folk theorem states that in infinitely repeated games, almost any outcome, including the best possible outcome, becomes a possible Nash equilibrium as long as players are sufficiently patient. In politics these players might include powerful bureaucrats deciding whether to become bribe-takers or political parties deciding whether to invest in stable long-run institutions at the expense of short-run political victories, for example. As long as the game is infinitely repeated, or at least always continues with some positive probability each round, the folk theorem suggests that greater patience raises the likelihood of good outcomes.

3. Public officials and private businesses alike will have greater concern for their reputations if they are more patient. Judges will worry more about their legacy, entrepreneurs will worry more about a reputation for product quality, and potential malefactors will worry more about what others will think about them. The "shadow of the future" (Axelrod, 1984) looms larger among the patient. 
There is another theoretical reason why groups with high cognitive skills may be more likely to build better institutions. This is because some of the most important economic ideas are often quite complicated, and difficult to understand without abstract thought about indirect consequences. Caplan and Miller (2010) found that in the General Social Survey, high IQ respondents were more likely to agree with economists on the relative merits of market-oriented policies, confirming that the higher-scoring are more likely to perceive the relative benefits of market competition and to understand the hidden costs of some well-intended government regulations. The abstract thinking abilities measured by some IQ tests are likely useful in understanding the non-obvious concept that in some cases, self-interest leads businesspeople and workers to serve the public interest. Therefore, the Caplan and Miller results suggest that other things equal, populations with higher average IQ will be more likely to support the indirect, non-obvious, market-oriented approach to organizing economic activity rather than the direct, more obvious, and generally less effective command-and-control approach.

Since good economic institutions are in many ways a public good-produced by individual politicians, bureaucrats, and citizens who do not reap the full benefits of their efforts to sustain the institutions, and where an incentive to free-ride off of the efforts of others is rational in the short run-it is noteworthy that Putterman et al. (2011) found that students with higher IQ scores contributed more to the common good in a repeated public goods game. These authors also found that when the game included the opportunity to vote on punishments for players who did not contribute to the public good, participants with higher IQs were more likely to vote for the most rational, most efficient punishment mechanism. Thus the Putterman et al. results support both the public goods and the voting mechanisms of the IQ-institutional quality relationship.

And since political cooperation has elements of a prisoner's dilemma-where each actor has an incentive to betray the other or seek a short-run gain, but where cooperation maximizes the joint surplus-it is similarly noteworthy that Jones 
(2008) found that students at American universities with high SAT scores tended to be more cooperative than students at lower-scoring universities in a repeated prisoner's dilemma. Segal and Hershberger (1999) similarly found that twins playing a repeated prisoner's dilemma against each other tended to cooperate more often when players had higher average IQs. If building good economic institutions involves resolving repeated prisoner's dilemmas and finding ways to encourage individuals to contribute to the public good then experimental evidence thus far suggests that cognitive skills may be an important contributor to institutional quality. Finally, in a one-shot game, Shaw et al. (2013) show that high IQ participants were less likely to bribe than low IQ participants.

Countries with better institutions are likely to have greater prosperity, healthier environments, higher quality education establishments, and hence higher levels of human capital, so causation may also run from institutions to cognitive skills. But the patience, understanding, and cooperation channels are likely to be of substantial significance given the supportive microfoundational evidence from psychology and economics experiments. Our cross-country regressions will control for some preexisting factors contributing to good institutions, and also control for GDP per capita, a possible independent driver of cognitive skills.

Previous work has demonstrated that nations that currently have higher cognitive skills indeed have better economic institutions by some measures. Lynn and Vanhanen $(2002,2006)$ report strong positive bivariate correlations, and Potrafke (2012) reports that national cognitive skill predicts lower corruption after including a variety of controls. Kalonda-Kanyama (2014) shows that high IQ countries have better institutions as measured by control of corruption, government efficiency, regulatory quality and rule of law. Kodila-Tedika (2012) uses data for Africa and reports that high IQ countries had better governance. Lynn and Vanhanen (2012b) describe many correlates of national IQs, including levels of economic freedom. 
Berggren and Bjørnskov (2013) examine whether religiosity promotes property rights protection and rule of law as measured by the indices of the Heritage Foundation and the World Governance indicators (Kaufmann et al., 2008). The authors include IQ for a robustness test and show that high IQ countries tend to have secure property rights and sound rule of law.

In past work in the economics, infectious disease (Eppig et al., 2010), and psychology literatures, a widely-used measure of cognitive skill has been the national average IQ estimates of Lynn and Vanhanen $(2002,2006)$ and Lynn and Meisenberg (2010a, b); we use the most recent update of this measure (Lynn \& Vanhanen, 2012a), which we discuss below. One of our innovations is to also use a new set of national cognitive skill estimates created by Rindermann et al. (2009) based entirely on PISA and TIMSS scores. These scores are valuable in two ways: First, because of their use by Hanushek and coauthors (2000, 2011, 2012), PISA and TIMSS scores are more familiar to economists than the national IQ measures. There is high correlation between IQ and the (possibly) better measured PISA and TIMSS scores (Rindermann, 2007). And second, Rindermann and coauthors $(2009,2011)$ use data on standard deviations to estimate $5^{\text {th }}$ and $95^{\text {th }}$ percentile cognitive skill scores for each country. This will allow us to give preliminary tests of three different hypotheses about the link between cognitive skill and institutional outcomes: The weakest link theory, the median voter theory, and the smart fraction theory.

\section{Data and descriptive statistics}

The national average IQ data come from Lynn and Vanhanen (2012a). These 2012 IQ data are updates of Lynn and Vanhanen $(2002,2006)$ and from Lynn and Meisenberg (2010a, 2010b). Henceforth we refer to these as the Lynn estimates: They draw on a wide variety of journal articles, international cognitive tests, and comprehensive samples assembled by IQ testing companies. Cognitive testing has become common around the world, and the Lynn estimates are the first comprehensive aggregation of these previously-existing test scores. Lynn and 
coauthors use the mean (in the 2002 data) or the median (in later data) when multiple estimates are available for the same country. When IQ data are aggregated across time, the Lynn estimates adjust for the Flynn effect, the widely-documented upward trend in national average IQ scores.

The Lynn estimates use a modest number of interpolations from nearby countries; earlier versions of these interpolated data have been used in the infectious disease literature (Eppig et al., 2010), providing evidence that infectious disease burden predicts lower national average IQ. In past work, the interpolated observations have been highly correlated with PISA and TIMSS scores and with later, nation-based national IQ estimates, so we employ these interpolated observations in the results reported below.

The Lynn estimates are the first of their kind and have been used across the social and biological sciences (inter alia, Eppig et al., 2010; Jones \& Schneider, 2006, 2010; Ram, 2007; Weede \& Kämpf, 2002). In the 2012 dataset, average IQ in the UK is equal to 99. Global mean IQ (unweighted by country size) is 90 IQ points and the standard deviation across countries in the 2002 data is 11 IQ points. By comparison, the standard deviation of IQ within a typical rich country equals 15 IQ points.

The most serious critique of the Lynn estimates comes from a series of papers by Wicherts et al. (2009, 2010a, 2010b) who focus on the quality of the sub-Saharan African data; the debate between these authors and Lynn and Meisenberg (2010a, $2010 \mathrm{~b}$ ) is worthy of attention. Wicherts et al. explicitly focus on healthy sub-Saharan African populations of normal socio-economic status in creating their alternative collection of sub-Saharan African IQ tests, and report a mean sub-Saharan African IQ of 80. It is possible that given their methodology they overestimate current average sub-Saharan African human capital levels, due to their focus on healthy, normal SES samples. Wicherts et al. treat their IQ estimates as potentially reflecting genuine differences in current cognitive skill; they recommend better prenatal and childhood 
nutrition, better education, higher urbanization levels, and other reforms to improve scores in sub-Saharan Africa.

To address the very real possibility that the Wicherts scores are higher quality than the Lynn estimates, we run additional specifications Winsorizing all sub-Saharan African IQ scores to a minimum of 76 (the median sub-Saharan African estimate among the highest-quality studies of K-12 students in Wicherts et al. (2010a, 2010b)) and again to 80, their average estimate of recent sub-Saharan African IQ measured by the non-verbal Raven's Progressive Matrices (Wicherts et al., 2009). The Winsorizing does not change the inferences.

Rindermann et al. (2009) created a separate database of cognitive ability scores derived from PISA and TIMSS scores; they normalize these scores to a mean of 100 and standard deviation of 15 to be comparable to IQ scores. The authors also make some adjustments because sample sizes are more representative in some countries than others. PISA and TIMSS both report standard deviations for each country; by assuming normality, Rindermann et al. create $95^{\text {th }}$ and $5^{\text {th }}$ percentile scores for each country. ${ }^{3}$ Rinderman and Thompson (2011) find that these measures predict economic freedom and scientific achievement.

Our institutional measure is the International Property Rights Index and its subindices. The International Property Rights Index is a new measure of institutional quality created by the Property Rights Alliance, an affiliate of Americans for Tax Reform. These data were first published in 2007 and updated in the last years (data and descriptive reports are available at www.internationalpropertyrightsindex.org). We use the 2012 version which includes data available for up to 130 countries.

The overall Index value for each country is a composite of three subindices: Legal and Political Environment, Physical Property Rights, and Intellectual Property

\footnotetext{
${ }^{3}$ Rindermann (2012) updated the data.
} 
Rights. The first measures the absence of corruption and political stability, the second ease of property registration; the third is self-explanatory. Since economists tend to place weight on property rights as a key economic institution this index is useful for testing the hypothesis that group cognitive skill fosters better institutions. The property rights index is measured on a scale of 1 to 10 . IQ and the CA scores are positively correlated with property rights protection. Correlation coefficients between Overall IPRI and IQ (2012) are 0.63, CA mean 0.54, CA 95 0.58, CA 50.48. Countries with high-IQ populations and strong property rights protection include Hong Kong, Singapore and Japan.

\section{Empirical model}

The baseline cross-sectional regression model has the following form:

Property Rights Index ${ }_{i}=\alpha_{\mathrm{k}}$ Cognitive Skills $_{i k}+\Sigma_{\mathrm{l}} \beta_{\mathrm{l}}$ Continent $_{\mathrm{il}}$

$$
+\sum_{\mathrm{m}} \gamma_{\mathrm{m}} \text { Legal Origin }_{\mathrm{im}}+\Sigma_{\mathrm{n}} \delta_{\mathrm{n}} \mathrm{x}_{\mathrm{in}}+\mathrm{u}_{\mathrm{i}}
$$

with $\mathrm{i}=1, \ldots, 130 ; \mathrm{k}=1, \ldots, 4 ; \mathrm{l}=1, \ldots, 4 ; \mathrm{m}=1, \ldots, 4 ; \mathrm{n}=1,2$

The dependent variable Property Rights Index associates property rights in country i. Cognitive Skills $s_{\mathrm{ik}}$ describes the cognitive skills variables, which vary across specifications. We distinguish between IQ (2012), CA mean, CA 95, and CA 5 in our baseline model. Continent $\mathrm{il}_{\mathrm{l}}$ are continental dummy variables assuming the value one if country $\mathrm{i}$ belongs to continent $\mathrm{l}$ and zero otherwise. We distinguish between five continents: Africa (reference category) Asia, Europe, America and Oceania. Legal Origin $_{\mathrm{im}}$ are legal origin dummy variables (La Porta et al., 1999). These dummy variables help to capture the possibility that long-term factors such as geography or ease of colonization may have had different impacts on the institutional development in different regions of the world. We distinguish between five legal origins: British (reference category), French, German, Scandinavian and Socialist. Countries with French and Socialist legal origin have been shown to have less secure 
property rights (Glaeser \& Shleifer, 2002; Kalonda-Kanyama, 2014; La Porta et al., 1999). These legal origin dummies similarly capture an institutional development hypothesis: a nation's legal system has a long-lasting, independent influence on a nation's institutional quality.

The vector $x_{\mathrm{i}}$ contains two economic control variables: log GDP per capita (real) in 2005 is from the Penn World Tables, and the years of education measures come from Barro and Lee (2010). Average years of total schooling are measured as of the year 2005, from the Barro-Lee database. ${ }^{4}$ Log GDP per capita is included because log GDP per capita has been shown to be positively correlated with property rights (Berggren \& Bjørnskov, 2013). Likewise education is included because national IQ scores could be purely a side-effect of education, and because if one is testing the hypothesis that "human capital" influences institutional quality, years of education are a competing index of human capital that could conceivably be a force generating higher-quality institutions. Table 1 shows descriptive statistics of all variables. Tables $2 \mathrm{a}$ and $2 \mathrm{~b}$ show correlation coefficients for the variables included (for the IQ sample and the somewhat smaller sample using the Rindermann et al. cognitive skill variables). We estimate the model with ordinary least squares (OLS) and classical standard errors. We cannot reject the null hypothesis of a Breusch-Pagan / CookWeisberg test for heteroskedasticity that the variance of the error terms is constant. Inferences do however not change when we use robust standard errors. We report standardized coefficients (mean zero, standard deviation one).

\section{Results}

Tables 3 and 4 show the results. The cognitive skill measures have bivariate correlations of between 0.48 and 0.63 with the property rights index. Controlling for continent dummies does not change this strong relationship. The IQ (2012) variable is statistically significant at the $1 \%$ level in all specifications in Table 3 . Table 4 shows the results for the Rindermann et al. (2009) cognitive ability variables. The

\footnotetext{
${ }^{4}$ We use average years of total schooling (\% of population aged 15 and over) in the baseline model. Inferences do not change when we use average years of total schooling (\% of population aged 25 and over).
} 
CA mean variable is statistically significant at the $1 \%$ level in columns (1) and (2), at the $5 \%$ level in column (3), but lacks statistical significance in column (4). The $95^{\text {th }}$ percentile CA variable is statistically significant at the $1 \%$ level in columns (5) and (6) and at the $5 \%$ level in columns (7) and (8). The $5^{\text {th }}$ percentile CA variable is statistically significant at the $1 \%$ level in columns (9) and (10), but lacks statistical significance in columns (11) and (12). The 5th percentile has a more fragile relationship with institutional quality. The relative fragility of the 5th percentile provides little evidence for a "weakest link" theory, where the cognitive skills of the poorer performers have a strong effect on institutional quality.

Simultaneously adding controls for legal origin and log GDP per capita, reduces the effect size of all coefficients. Inclusion of years of total schooling as a control does not substantially change these results. The IQ measure remains a statistically significant predictor of institutional quality, as does $95^{\text {th }}$ percentile CA. Average years of total schooling do not turn out to be statistically significant in Tables 3 and 4. Log GDP per capita has the expected positive sign and is statistically significant at the $1 \%$ level in Tables 3 and $4 . .^{5}$ Countries with French and Socialist legal origin have less secure property rights than countries with British legal origin. These results are perfectly in line with previous findings (Berggren \& Bjørnskov 2013; Glaeser \& Shleifer, 2002; Kalonda-Kanyama, 2014; La Porta et al., 1999).

With statistical significance established we turn to quantitative significance. The numerical meaning of the coefficient of the IQ (2012) variable in column 1, Table 3 is that when the IQ (2012) variable increases by one standard deviation, the overall IPR Index increases by about 0.69 points (about 0.5 standard deviations). The numerical meaning of the coefficient of the CA mean variable in column 1, Table 4 is that when the CA mean variable increases by one standard deviation, the overall IPR Index increases by about 0.62 points. When all controls are included, the numerical effects are smaller: for example, a one standard deviation increase in national average IQ (2012) predicts an increase in the property rights index of about 0.27

${ }^{5}$ Average years of total schooling is statistically significant when GDP per capita is not included. 
points (column 4 in Table 3). The full-control specifications may be lower bound estimates, since they eliminate the possibility that, for instance, higher cognitive skills directly raise a nation's GDP per capita or the derived demand for education, which in turn promote institutional quality. The Rindermann et al. (2009) cognitive ability results yield similar size effects.

We have replaced the overall property rights protection indicator by the subindicators on legal, physical, intellectual property rights protection. The IQ variables have a large effect on the legal property rights index, and a much smaller effect on the physical property rights index. Intellectual property protection has an especially strong relationship with $95^{\text {th }}$ percentile CA, which may drive the overall result.

Winsorizing the sub-Saharan African IQ scores to a minimum of 76 or 80 does not substantially change any of the above results; for the overall property rights index, results are modestly more robust with the Winsorized data.

Inferences also do not change when we use the 2002, 2006, 2010 IQ data.

We estimated the models including IQ for the somewhat smaller sample for which the Rindermann et al. measures are available. Inferences do not change.

\section{Conclusion}

Economists have long searched for fundamental causes of good economic performance, and many have long believed that some economic institutions were better than others at achieving good performance. However, the causes of good institutions have remained a topic of controversy.

The results presented here are consistent with the hypothesis that higher levels of cognitive skill help citizens to become more patient and better informed. Thus, such citizens may be more likely to perceive the benefits of the impartial rule of law and more likely to enforce rules even when those rules impose a short-run cost. 
Fortunately, psychologists and others have investigated how to raise broad-based cognitive skills and multiple channels appear to exist for raising IQ and other measures of cognitive skills (Armor, 2003; Behrman et al., 2004; Sternberg, 2008). Also, the Flynn Effect (Flynn, 1987; Neisser, 1998; Williams, 2013), the still poorlyunderstood long-run rise in IQ scores documented in developed countries in the $20^{\text {th }}$ century, appears to have only begun in the poorest countries (Nisbett et al., 2012). The Flynn Effect is of course strong evidence for large recent environmental influences on some types of cognitive skill. Policies that improve the nutrition, educational quality and the natural environment of the world's poorest nations will, one hopes, have substantial effects on long-run institutional quality.

\section{Acknowledgements}

We would like to thank Christian Bjørnskov, Susan M. Collins, Eric Hanushek two anonymous referees and the participants at the American Economic Association meetings 2014 in Philadelphia for their very helpful comments, hints, and suggestions. We are also very grateful to Ha Quyen Ngo for her excellent research assistance. 


\section{Bibliography}

Armor, D. J. (2003). Maximizing intelligence. New Brunswick: Transaction Publishers.

Axelrod, R. (1984). The Evolution of Cooperation. New York: Basic Books.

Barro, R. J. \& Gordon, D.B. (1983). Rules, discretion and reputation in a model of monetary policy. Journal of Monetary Economics, 12, 101-121.

Barro, R. J. \& Lee, J.W. (2010). A new data set of educational attainment in the world, 1950-2010. NBER Working Paper No. 15902.

Behrman, J., Alderman, H. \& Hoddinott, J. (2004). Copenhagen ConsensusChallenges and Opportunities: Hunger and Malnutrition.

CopenhagenConsensus.com.

Berggren, N. \& Bjørnskov, C. (2013). Does religiosity promote property rights and rule of law?. Journal of Institutional Economics, 9, 161-185.

Caplan, B. \& Miller, S.C. (2010). Intelligence Makes People Think Like Economists: Evidence from the General Social Survey. Intelligence, 38, 636-47.

Côté, S \& and Miners, C.T.H. (2006). Emotional Intelligence, Cognitive Intelligence, and Job Performance. Administrative Science Quarterly, 1-28.

Dohmen ,T., Falk, A., Huffman, D. \& Sunde, U. (2010). Are Risk Aversion and Impatience Related to Cognitive Ability?. American Economic Review, 100, 12381260.

Eppig, C., Fincher, C.L. \& Thornhill, R. (2010). Parasite prevalence and the worldwide distribution of cognitive ability. Proceedings of the Royal Society B: Biological Sciences, 277, 3801-3808.

Flynn, J.R. (1987). Massive IQ gains in 14 nations: What IQ tests really measure. Psychological Bulletin, 101, 171-191.

Glaeser, E.L \& Shleifer, A. (2002). Legal origins. Quarterly Journal of Economics, 117, 1193-1229.

Hanushek, E.A. \& Kimko, D.D. (2000). Schooling, labor-force quality, and the growth of nations. American Economic Review, 90, 1184-1208.

Hanushek, E.A. \& Woessmann, L. (2011). The economics of international differences in educational achievement. In E. A. Hanushek, S. Machin \& L. Woessmann (Eds.), Handbook of the Economics of Education Vol. 3 (pp. 89-200). Amsterdam: North Holland. 
Hanushek, E.A. \& Woessmann, L. (2012). Do better schools lead to more growth? Cognitive skills, economic outcomes, and causation. Journal of Economic Growth, 17, 267-321.

Jones, G. \& Schneider, W.J. (2006). Intelligence, human capital and economic growth: A Bayesian averaging of classical estimates (BACE) approach. Journal of Economic Growth, 11, 71-93.

Jones, G. (2008). Are smarter groups more cooperative? Evidence from prisoner's dilemma experiments, 1959-2003. Journal of Economic Behavior \& Organization, 68, 489-497.

Jones, G. \& Schneider, W.J. (2010). IQ in the production function: evidence from immigrant earnings. Economic Inquiry, 48, 743-755.

Kalonda-Kanyama, I. (2014). Quality of institutions: Does intelligence matter?. Intelligence, 42, 44-52.

Kaufmann, D., Kraay, A. \& Mastruzzi, M., (2008). Governance matters VII: Aggregate and individual governance indicators 1996-2007. World Bank Policy Research Working Paper No. 4654, The World Bank, Washington, DC.

Kodila-Tedika, O. (2012). Governance and intelligence: Empirical analysis from African data. MPRA Working Paper No. 39937.

La Porta, R., Lopez-di-Silanes, F., Shleifer, A. \& Vishny, R. (1999). The quality of government. Journal of Law, Economics and Organization, 15, 222-279.

Lynn, R. \& Meisenberg, G. (2010a). National IQs calculated and validated for 108 nations. Intelligence, 38, 353-360.

Lynn, R. \& Meisenberg, G. (2010b). The average IQ of sub-Saharan Africans: Comments on Wicherts, Dolan, and van der Maas. Intelligence, 38, 21-29.

Lynn, R. \& Vanhanen, T. (2002). IQ and the Wealth of Nations. Westport, CT: Praeger Publishers.

Lynn, R. \& Vanhanen, T. (2006). IQ and Global Inequality. Augusta, GA: Washington Summit Publishers.

Lynn, R. \& Vanhanen, T. (2012a). National IQs: A review of their educational, cognitive, economic, political, demographic, sociological, epidemiological, geographic and climatic correlates. Intelligence, 40, 226-234. 
Lynn, R. \& Vanhanen, T. (2012b). Intelligence: A Unifying Construct for the Social Sciences. London: Ulster Institute for Social Research.

Neisser, U. (Ed.) (1998). The rising curve: Long-term gains in IQ and related measures. American Psychological Association, 10, 10270-10300.

Nisbett, R.E., Aronson, J., Blair, C., Dickens, W., Flynn, J., Halpern, D.F. \& Turkheimer, E. (2012). Intelligence: new findings and theoretical developments. American Psychologist, 67, 130.

Potrafke, N. (2012). Intelligence and Corruption. Economics Letters, 114, 109-112.

Putterman, L., Tyran, J.R. \& Kamei, K. (2011). Public goods and voting on formal sanction schemes. Journal of Public Economics, 95, 1213-1222.

Ram, R. (2007). IQ and economic growth: Further augmentation of Mankiw-RomerWeil model. Economics Letters, 94, 7-11.

Ree M.J. \& Earles J.A. (1992). Intelligence Is the Best Predictor of Job Performance. Current Directions in Psychological Science, 1, 86-89.

Rindermann, H. (2007). The g-factor of international cognitive ability comparisons: The homoegeneity of results in PISA, TIMSS, PIRLS and IQ-tests across nations. European Journal of Personality, 21, 667-706.

Rindermann, H. (2012). Intellectual classes, technological progress and economic development: The rise of cognitive capitalism. Personality and Individual Differences, 53, 108-113.

Rindermann, H., Sailer, M. \& Thompson, J. (2009). The impact of smart fractions, cognitive ability of politicians and average competence of peoples on social development. Talent Development \& Excellence, 1, 3-25.

Rindermann, H. \& Thompson, J. (2011). Cognitive capitalism: the effect of cognitiveability on wealth, as mediated through scientific achievement and economic freedom. Psychological Science, 22, 754-763.

Segal, N.L. \& Hershberger, S.L. (1999). Cooperation and competition between twins: findings from a prisoner's dilemma game. Evolution and Human Behavior, 20, 29-51.

Shamosh, N. \& Gray, R. (2008). Delay discounting and intelligence: A meta-analysis. Intelligence, 36, 289-305.

Shaw, P., Vásquez, W.F. \& LeClair, M. (2013). Intelligence and bribing behavior in a one-shot game. Journal of Socio-Economics, 44, 91-96. 
Shoda, Y., Mischel, W. \& Peake, P.K. (1990). Predicting Adolescent Cognitive and SelfRegulatory Competencies from Preschool Delay of Gratification: Identifying Diagnostic Conditions. Developmental Psychology, 26, 978-986.

Sternberg, R.J. (2008). Increasing fluid intelligence is possible after all. Proceedings of the National Academy of Sciences, 105, 6791-6792.

Warner, J.T. \& Pleeter, S. (2001). The Personal Discount Rate: Evidence from Military Downsizing Programs. American Economic Review, 91, 33-53.

Weede, E. \& Kämpf, S. (2002). The impact of intelligence and institutional improvements on economic growth. Kyklos, 55, 361-380.

Wicherts, J.M., Dolan, C.V., Carlson, J.S. \& van der Maas, H.L.J. (2009). Raven's test performance of sub-Saharan Africans: Average performance, psychometric properties, and the Flynn Effect. Learning and Individual Differences, 20, 135-151.

Wicherts, J.M., Dolan, C.V., Carlson, J.S. \& van der Maas, H.L.J. (2010a). A systematic literature review of the average IQ of sub-Saharan Africans. Intelligence, 38, 1-20.

Wicherts, J.M., Dolan, C.V., Carlson, J.S. \& van der Maas, H.L.J. (2010b). Another failure to replicate Lynn's estimate of the average IQ of sub-Saharan Africans". Learning and Individual Differences, 20, 155-157.

Williams, R.L. (2013). Overview of the Flynn effect. Intelligence, 41, 753-764. 
Table 1: Descriptive statistics and data sources.

\begin{tabular}{|c|c|c|c|c|c|c|}
\hline Variable & Observations & Mean & Std. Dev. & Min & Max & Source \\
\hline IPRI overall & 130 & 5.60 & 1.38 & 3.00 & 8.60 & $\begin{array}{l}\text { Property Rights Alliance } \\
\text { (2012) }\end{array}$ \\
\hline IPRI legal & 130 & 5.24 & 1.80 & 2.20 & 8.80 & $\begin{array}{l}\text { Property Rights Alliance } \\
\text { (2012) }\end{array}$ \\
\hline IPRI physical & 130 & 6.19 & 1.00 & 2.90 & 8.40 & $\begin{array}{l}\text { Property Rights Alliance } \\
\text { (2012) }\end{array}$ \\
\hline IPRI intellectual & 130 & 5.37 & 1.64 & 1.70 & 8.60 & $\begin{array}{l}\text { Property Rights Alliance } \\
\text { (2012) }\end{array}$ \\
\hline IQ (2002) & 113 & 87.53 & 11.21 & 63 & 107 & Lynn and Vanhanen (2002) \\
\hline IQ (2006) & 114 & 87.27 & 11.63 & 64 & 108 & Lynn and Vanhanen (2006) \\
\hline IQ (2010) & 95 & 89.99 & 10.42 & 60 & 108 & $\begin{array}{l}\text { Lynn and Meisenberg } \\
\text { (2010a) }\end{array}$ \\
\hline IQ (2012) with min IQ Africa 76 & 130 & 87.79 & 8.92 & 71 & 106.90 & $\begin{array}{l}\text { Lynn and Vanhanen (2012a), } \\
\text { own calculations }\end{array}$ \\
\hline IQ (2002) with min IQ Africa 76 & 113 & 88.72 & 9.38 & 72 & 107 & $\begin{array}{l}\text { Lynn and Vanhanen (2002), } \\
\text { own calculations }\end{array}$ \\
\hline IQ (2006) with min IQ Africa 76 & 114 & 88.67 & 9.49 & 71 & 108 & $\begin{array}{l}\text { Lynn and Vanhanen (2006), } \\
\text { own calculations }\end{array}$ \\
\hline IQ (2010) with min IQ Africa 76 & 95 & 90.80 & 8.83 & 76 & 108 & $\begin{array}{l}\text { Lynn and Meisenberg } \\
\text { (2010a), own calculations }\end{array}$ \\
\hline IQ2012) with min IQ Africa 80 & 130 & 88.51 & 8.06 & 71 & 106.90 & $\begin{array}{l}\text { Lynn and Vanhanen (2012a), } \\
\text { own calculations }\end{array}$ \\
\hline GDP per capita 2005 & 130 & 14499.41 & 15568.18 & 323.26 & 73242.97 & Penn World Tables 7.1 \\
\hline Africa & 130 & 0.24 & 0.43 & 0 & 1 & own calculations \\
\hline Asia & 130 & 0.27 & 0.45 & 0 & 1 & own calculations \\
\hline Europe & 130 & 0.29 & 0.46 & 0 & 1 & own calculations \\
\hline America & 130 & 0.18 & 0.39 & 0 & 1 & own calculations \\
\hline Oceania & 130 & 0.02 & 0.12 & 0 & 1 & own calculations \\
\hline Legal Origin (british) & 128 & 0.27 & 0.45 & 0 & 1 & La Porta et al. (1999) \\
\hline Legal Origin (french) & 128 & 0.46 & 0.50 & 0 & 1 & La Porta et al. (1999) \\
\hline Legal Origin (german) & 128 & 0.05 & 0.21 & 0 & 1 & La Porta et al. (1999) \\
\hline Legal Origin (scandinavian) & 128 & 0.04 & 0.19 & 0 & 1 & La Porta et al. (1999) \\
\hline Legal Origin (socialist) & 128 & 0.18 & 0.39 & 0 & 1 & La Porta et al. (1999) \\
\hline $\begin{array}{l}\text { Avg. years of total schooling (\% of } \\
\text { population aged } 15 \text { and over) } 2005\end{array}$ & 116 & 8.17 & 2.52 & 1.24 & 12.75 & Barro and Lee (2010) \\
\hline $\begin{array}{l}\text { Avg. years of total schooling (\% of } \\
\text { population aged } 25 \text { and over) } 2005\end{array}$ & 116 & 7.85 & 2.79 & 1.07 & 13.09 & Barro and Lee (2010) \\
\hline
\end{tabular}


Table 2a: Correlation matrix with IQ scores (116 observations).

\begin{tabular}{|c|c|c|c|c|c|c|c|}
\hline 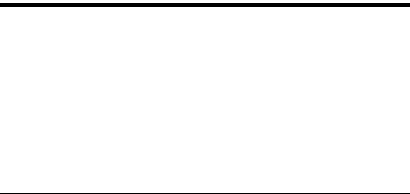 & IPRI overall & IPRI legal & $\begin{array}{c}\text { IPRI } \\
\text { physical }\end{array}$ & $\begin{array}{c}\text { IPRI } \\
\text { intellectual }\end{array}$ & IQ (2012) & $\begin{array}{l}\text { GDP per capita } \\
2005\end{array}$ & $\begin{array}{l}\text { Avg. years of total } \\
\text { schooling (\% of } \\
\text { population aged } 15 \\
\text { and over) } 2005\end{array}$ \\
\hline IPRI overall & 1 & & & & & & \\
\hline IPRI legal & .96 & 1 & & & & & \\
\hline IPRI physical & .88 & .79 & 1 & & & & \\
\hline IPRI intellectual & .95 & .86 & .77 & 1 & & & \\
\hline IQ (2012) & .63 & .64 & .49 & .59 & 1 & & \\
\hline GDP per capita 2005 & .77 & .79 & .62 & .72 & .57 & 1 & \\
\hline $\begin{array}{l}\text { Avg. years of total } \\
\text { schooling (\% of } \\
\text { population aged } 15 \text { and } \\
\text { over) } 2005\end{array}$ & .61 & .63 & .45 & .58 & .76 & .53 & 1 \\
\hline
\end{tabular}


Table 2b: Correlation matrix with CA scores (76 observations).

$\begin{array}{cccccccc}\text { IPRI } & \text { IPRI } & \text { IPRI } & \text { IPRI } & \text { CA } & \text { CA } & \text { CA } & \text { GDP per } \\ \text { overall } & \text { legal } & \text { physical } & \text { intellectual } & \text { Avg. years of total schooling } \\ \text { (\% of population aged 15 } & 95 & 5 & \begin{array}{c}\text { capita } \\ \text { and over) 2005 }\end{array} & \begin{array}{c}2005 \\ \hline\end{array}\end{array}$

\begin{tabular}{|c|c|c|c|c|c|c|c|c|c|}
\hline IPRI overall & 1 & & & & & & & . & dilu over) $<003$ \\
\hline IPRI legal & .97 & 1 & & & & & & & \\
\hline IPRI physical & .87 & .79 & 1 & & & & & & \\
\hline IPRI intellectual & .94 & .87 & .72 & 1 & & & & & \\
\hline CA Mean & .54 & .57 & .33 & .55 & 1 & & & & \\
\hline CA 95 & .57 & .58 & .33 & .60 & .97 & 1 & & & \\
\hline CA 5 & .50 & .52 & .32 & .49 & .98 & .91 & 1 & & \\
\hline GDP per capita 2005 & .78 & .78 & .63 & .72 & .45 & .44 & .43 & 1 & \\
\hline $\begin{array}{l}\text { Avg. years of total schooling } \\
\text { (\% of population aged } 15 \\
\text { and over) } 2005\end{array}$ & .52 & .55 & .28 & .54 & .72 & .75 & .64 & .39 & 1 \\
\hline
\end{tabular}


Table 3: Regression results with standardized beta coefficients. Dependent variable: Overall IPR Index. OLS with classical standard errors. IQ scores.

\begin{tabular}{|c|c|c|c|c|}
\hline & (1) & (2) & (3) & (4) \\
\hline \multirow[t]{2}{*}{ IQ (2012) } & $.690^{* * *}$ & $.597 * * *$ & $.283^{* * *}$ & $.274 * * *$ \\
\hline & $(6.24)$ & (6.30) & $(2.90)$ & (2.65) \\
\hline \multirow[t]{2}{*}{ Asia } & -.173 & -.067 & $-.191 * *$ & $-.210 * *$ \\
\hline & (1.57) & $(0.75)$ & (2.37) & (2.52) \\
\hline \multirow[t]{2}{*}{ Europe } & -.106 & $.214^{*}$ & -.009 & -.010 \\
\hline & $(.78)$ & (1.83) & $(0.08)$ & (0.09) \\
\hline \multirow[t]{2}{*}{ America } & -.145 & -.078 & $-.192 * * *$ & $-.215^{* * *}$ \\
\hline & $(1.54)$ & (1.03) & $(2.78)$ & $(2.91)$ \\
\hline \multirow[t]{2}{*}{ Oceania } & .084 & .077 & .030 & .023 \\
\hline & (1.10) & (1.23) & $(0.55)$ & $(0.40)$ \\
\hline \multirow[t]{2}{*}{ Legal Origin (french) } & & $-.229 * * *$ & $-.210 * * *$ & $-.225 * * *$ \\
\hline & & (3.36) & $(3.52)$ & (3.31) \\
\hline \multirow[t]{2}{*}{ Legal Origin (scandinavian) } & & .060 & .067 & .059 \\
\hline & & $(0.94)$ & $(1.21)$ & $(1.01)$ \\
\hline \multirow[t]{2}{*}{ Legal Origin (german) } & & -.012 & .011 & .004 \\
\hline & & $(0.20)$ & $(0.20)$ & $(0.07)$ \\
\hline \multirow[t]{2}{*}{ Legal Origin (socialist) } & & $-.553 * * *$ & $-.381 * * *$ & $-.379 * * *$ \\
\hline & & (7.32) & $(5.31)$ & $(5.02)$ \\
\hline \multirow[t]{2}{*}{ log per capita GDP } & & & $.514^{* * *}$ & $.500 * * *$ \\
\hline & & & $(6.12)$ & (5.10) \\
\hline \multirow[t]{2}{*}{ Avg. years of total schooling (\% of population aged 15 and over) 2005} & & & & .018 \\
\hline & & & & $(0.18)$ \\
\hline Observations & 130 & 128 & 128 & 115 \\
\hline r2 & .433 & .664 & .745 & .754 \\
\hline
\end{tabular}

Notes: Absolute value of $\mathrm{t}$ statistics in parentheses; * significant at $10 \%$; ** significant at $5 \%$; *** significant at $1 \%$ 


\begin{tabular}{|c|c|c|c|c|c|c|c|c|c|c|c|c|}
\hline & $(1)$ & $(2)$ & (3) & $(4)$ & (5) & (6) & $(7)$ & (8) & (9) & $(10)$ & $(11)$ & $(12)$ \\
\hline CA Mean & $\begin{array}{c}.618^{* * * *} \\
(4.99)\end{array}$ & $\begin{array}{c}.418^{* * *} \\
(4.44)\end{array}$ & $\begin{array}{l}.180 * * \\
(2.10)\end{array}$ & $\begin{array}{c}.153 \\
(1.56)\end{array}$ & & & & & & & & \\
\hline CA 95 & & & & & $\begin{array}{c}.632 * * * \\
(5.47)\end{array}$ & $\begin{array}{c}.427 * * * \\
(4.72)\end{array}$ & $\begin{array}{l}.209 * * \\
(2.58)\end{array}$ & $\begin{array}{l}.203 * * \\
(2.10)\end{array}$ & & & & \\
\hline CA 5 & & & & & & & & & $\begin{array}{c}.514 * * * \\
(4.00)\end{array}$ & $\begin{array}{c}.353^{* * *} \\
(3.78)\end{array}$ & $\begin{array}{l}.130 \\
(1.59)\end{array}$ & $\begin{array}{l}.113 \\
(1.26)\end{array}$ \\
\hline Asia & $\begin{array}{l}-.311^{*} \\
(1.70)\end{array}$ & $\begin{array}{l}-.084 \\
(0.67)\end{array}$ & $\begin{array}{c}-.224^{* *} \\
(2.16)\end{array}$ & $\begin{array}{l}-.205^{*} \\
(1.96)\end{array}$ & $\begin{array}{l}-.262 \\
(1.51)\end{array}$ & $\begin{array}{l}-.055 \\
(0.46)\end{array}$ & $\begin{array}{c}-.218^{* *} \\
(2.17)\end{array}$ & $\begin{array}{c}-.209 * * \\
(2.06)\end{array}$ & $\begin{array}{l}-.264 \\
(1.37)\end{array}$ & $\begin{array}{l}-.055 \\
(0.42)\end{array}$ & $\begin{array}{c}-.211^{* *} \\
(2.00)\end{array}$ & $\begin{array}{l}-.194^{*} \\
(1.85)\end{array}$ \\
\hline America & $\begin{array}{l}-.156 \\
(1.06)\end{array}$ & $\begin{array}{l}-.037 \\
(0.37)\end{array}$ & $\begin{array}{l}-.143^{*} \\
(1.71)\end{array}$ & $\begin{array}{l}-.161^{*} \\
(1.81)\end{array}$ & $\begin{array}{l}-.127 \\
(0.90)\end{array}$ & $\begin{array}{l}-.021 \\
(0.22)\end{array}$ & $\begin{array}{l}-.142 * \\
(1.73)\end{array}$ & $\begin{array}{l}-.158^{*} \\
(1.81)\end{array}$ & $\begin{array}{l}-.108 \\
(0.70)\end{array}$ & $\begin{array}{l}-.001 \\
(0.01)\end{array}$ & $\begin{array}{l}-.129 \\
(1.53)\end{array}$ & $\begin{array}{l}-.156^{*} \\
(1.74)\end{array}$ \\
\hline Oceania & $\begin{array}{l}.034 \\
(0.29)\end{array}$ & $\begin{array}{c}.052 \\
(0.66)\end{array}$ & $\begin{array}{l}-.005 \\
(0.08)\end{array}$ & $\begin{array}{l}-.018 \\
(0.26)\end{array}$ & $\begin{array}{l}.028 \\
(0.25)\end{array}$ & $\begin{array}{c}.055 \\
(0.71)\end{array}$ & $\begin{array}{l}-.009 \\
(0.15)\end{array}$ & $\begin{array}{l}-.020 \\
(0.30)\end{array}$ & $\begin{array}{l}.087 \\
(0.73)\end{array}$ & $\begin{array}{c}.078 \\
(0.97)\end{array}$ & $\begin{array}{l}.007 \\
(0.11)\end{array}$ & $\begin{array}{l}-.014 \\
(0.20)\end{array}$ \\
\hline $\begin{array}{l}\text { Legal Origin } \\
\text { (french) }\end{array}$ & & $\begin{array}{c}-.367 * * * \\
(4.09)\end{array}$ & $\begin{array}{c}-.247 * * * \\
(3.29)\end{array}$ & $\begin{array}{c}-.222 * * \\
(2.64)\end{array}$ & & $\begin{array}{c}-.330 * * * \\
(3.63)\end{array}$ & $\begin{array}{c}-.226 * * * \\
(2.99)\end{array}$ & $\begin{array}{c}-.211^{* *} \\
(2.54)\end{array}$ & & $\begin{array}{c}-.414^{* * *} \\
(4.58)\end{array}$ & $\begin{array}{c}-.263 * * * \\
(3.49)\end{array}$ & $\begin{array}{c}-.224 * * \\
(2.65)\end{array}$ \\
\hline $\begin{array}{l}\text { Legal Origin } \\
\text { (scandinavian) }\end{array}$ & & $\begin{array}{c}.010 \\
(0.13)\end{array}$ & $\begin{array}{c}.043 \\
(0.68)\end{array}$ & $\begin{array}{c}.035 \\
(0.53)\end{array}$ & & $\begin{array}{c}.034 \\
(0.45)\end{array}$ & $\begin{array}{c}.054 \\
(0.87)\end{array}$ & $\begin{array}{c}.043 \\
(0.66)\end{array}$ & & $\begin{array}{l}-.013 \\
(0.16)\end{array}$ & $\begin{array}{c}.035 \\
(0.55)\end{array}$ & $\begin{array}{c}.030 \\
(0.44)\end{array}$ \\
\hline $\begin{array}{l}\text { Legal Origin } \\
\text { (german) }\end{array}$ & & $\begin{array}{l}-.065 \\
(0.89)\end{array}$ & $\begin{array}{l}-.022 \\
(0.37)\end{array}$ & $\begin{array}{l}-.031 \\
(0.50)\end{array}$ & & $\begin{array}{l}-.054 \\
(0.75)\end{array}$ & $\begin{array}{l}-.020 \\
(0.34)\end{array}$ & $\begin{array}{l}-.032 \\
(0.51)\end{array}$ & & $\begin{array}{l}-.063 \\
(0.83)\end{array}$ & $\begin{array}{l}-.017 \\
(0.28)\end{array}$ & $\begin{array}{l}-.029 \\
(0.46)\end{array}$ \\
\hline $\begin{array}{l}\text { Legal Origin } \\
\text { (socialist) }\end{array}$ & & $\begin{array}{c}-.805 * * * \\
(8.40)\end{array}$ & $\begin{array}{c}-.454 * * * \\
(4.72)\end{array}$ & $\begin{array}{c}-.482 * * * \\
(4.89)\end{array}$ & & $\begin{array}{c}-.769 * * * \\
(8.03)\end{array}$ & $\begin{array}{c}-.441 * * * \\
(4.70)\end{array}$ & $\begin{array}{c}-.477 * * * \\
(4.95)\end{array}$ & & $\begin{array}{c}-.850 * * * \\
(8.66)\end{array}$ & $\begin{array}{c}-.456 * * * \\
(4.62)\end{array}$ & $\begin{array}{c}-.485 * * * \\
(4.84)\end{array}$ \\
\hline log per capita GDP & & & $\begin{array}{c}.522 * * * \\
(6.19)\end{array}$ & $\begin{array}{c}.483^{* * *} \\
(5.40)\end{array}$ & & & $\begin{array}{c}.510 * * * \\
(6.21)\end{array}$ & $\begin{array}{c}.475^{* * *} \\
(5.46)\end{array}$ & & & $\begin{array}{c}.546 * * * \\
(6.50)\end{array}$ & $\begin{array}{c}.491^{* * *} \\
(5.44)\end{array}$ \\
\hline $\begin{array}{l}\text { Avg. years of total } \\
\text { schooling (\% of } \\
\text { population aged } 15 \\
\text { and over) } 2005\end{array}$ & & & & (1.24) & & & & $(0.88)$ & & & & $(1.61)$ \\
\hline $\begin{array}{l}\text { Observations } \\
\text { r2 }\end{array}$ & $\begin{array}{c}83 \\
.334\end{array}$ & $\begin{array}{l}81 \\
.725\end{array}$ & $\begin{array}{c}81 \\
.822\end{array}$ & $\begin{array}{l}75 \\
.822\end{array}$ & $\begin{array}{c}83 \\
.366\end{array}$ & $\begin{array}{l}81 \\
.733\end{array}$ & $\begin{array}{c}81 \\
.827\end{array}$ & $\begin{array}{c}75 \\
.828\end{array}$ & $\begin{array}{c}83 \\
.271\end{array}$ & $\begin{array}{l}81 \\
.708\end{array}$ & $\begin{array}{c}81 \\
.818\end{array}$ & $\begin{array}{c}75 \\
.820\end{array}$ \\
\hline
\end{tabular}

Notes: Absolute value of t statistics in parentheses; * significant at $10 \%$; ** significant at $5 \%$; *** significant at $1 \%$ 